\title{
Kesehatan telinga pada anak SMA Negeri 9 Manado
}

\author{
${ }^{1}$ Agung S. Selviyanti \\ ${ }^{2}$ Armenius Sondakh \\ ${ }^{2}$ R. E. C. Tumbel \\ ${ }^{1}$ Kandidat Skripsi Fakultas Kedokteran Universitas Sam Ratulangi Manado \\ ${ }^{2}$ Bagian Telinga Hidung Tenggorokan Kepala Leher Fakultas Kedokteran \\ Universitas Sam Ratulangi - RSUP Prof. Dr. R. D. Kandou Manado \\ Email: agungsri98@gmail.com
}

\begin{abstract}
Ear is one of the most important organs in human body. Around 20\% of information were obtained from both ears daily. If hearing disorder occurs in students, they will show abnormalities, decrease of study prestation, and difficulties in social adaptation. This study aimed to obtain data about external ear health of students in SMA Negeri 9 Manado. This was an observational descriptive study with a cross sectional approach. Total respondents were 35 students. Examinations of external ears were done by ear, nose, and throat specialists. The results showed that all students had normal earlobes. Ear canal examination showed that 10 students had cerumen in the right and left ear canals, and 1 student had cerumen in left ear canal. Examination of tympani membrane showed that there were 32 students had normal membranes, 1 student had perforation, retraction, and bombans of the right and left membranes, and 2 students could not be evaluated. Conclusion: Most students of SMA Negeri 9 Manado had normal ears.
\end{abstract}

Keywords: ear health, students of senior high school

\begin{abstract}
Abstrak: Telinga merupakan salah satu alat indra yang penting. Sebagai indra pendengaran, telinga dapat menyerap sebesar $20 \%$ informasi dari kehidupan sehari-hari. Jika terdapat gangguan indra pendengaran pada masa sekolah maka anak akan menunjukkan kelainan perkembangan, menurunnya hasil belajar, dan kesulitan penyesuaian dalam pergaulan. Penelitian ini bertujuan untuk mendapatkan gambaran kesehatan telinga siswa SMA Negeri 9 Manado. Penelitian ini menggunakan metode deskriptif observasional dengan pendekatan potong lintang. Sampel penelitian sebanyak 35 siswa. Pengambilan data dilakukan dengan pemeriksaan meatus akustikus eksterna oleh dokter spesialis bagian THT-KL. Hasil penelitian memperlihatkan semua siswa mempunyai daun telinga normal. Pemeriksaan liang telinga mendapatkan 10 siswa dengan serumen di telinga kanan dan kiri, dan 1 siswa dengan serumen hanya pada telinga kiri. Pemeriksaan membran timpani mendapatkan hasil normal umtuk telinga kanan dan kiri sebanyak 32 siswa; perforasi, retraksi, dan bombans telinga kanan dan kiri pada 1 siswa; dan 2 siswa dengan membran yang tidak dapat dievaluasi. Simpulan: Sebagian besar siswa SMA Negeri 9 Manado memiliki hasil normal.
\end{abstract}

Kata kunci: kesehatan telinga, siswa SMA

Telinga merupakan salah satu indra penting yang berperan besar dalam kehidupan sehari-hari. Organ ini mempunyai fungsi utama yaitu pendengaran dan keseim- bangan - tergantung reseptor khusus yang disebut sel rambut. Ketika mendengar, membran timpani bergetar dan gelombang suara memasuki kanal telinga, dan 
melewati 3 tulang kecil (maleolus, incus, stapes). ${ }^{1}$

Keseimbangan merupakan kombinasi dari organ sensor di dalam telinga, visual input, dan informasi yang didapatkan dari reseptor tubuh terutama sekitar sendi. Informasi diproses di serebelum dan korteks serebral. ${ }^{1}$

Gangguan pendengaran merupakan defisit sensorik yang paling sering pada populasi manusia dan memengaruhi lebih dari 400 juta orang di dunia. Menurut WHO, terdapat 360 juta orang di dunia yang mengalami gangguan pendengaran, hasil tersebut merupakan 5,3\% dari populasi dunia. Pada tahun 2012 terdapat 328 juta (91\%) orang dewasa, 183 juta lakilaki, 145 juta perempuan dan 32 juta (9\%) anak-anak mengalami gangguan pendengaran. Prevalensi gangguan pendengaran pada anak dan pada dewasa umur di atas 65 tahun terbanyak di Asia Selatan, Asia Pasifik, dan Afrika Sub Saharan. ${ }^{2}$ Berdasarkan data Riset Kesehatan Dasar (RISKESDAS) 2013 Kementerian Kesehatan Republik Indonesia, pada usia $\geq 5$ tahun didapatkan prevalensi gangguan pendengaran usia 5-14 tahun dan 15-24 tahun masing-masing 0,8\% serta prevalensi ketulian pada usia yang sama yaitu masingmasing 0,04\%. Berdasarkan Provinsi, prevalensi gangguan pendengaran tertinggi terdapat di Nusa Tenggara Timur (3,7\%), Sulawesi Utara (2,4\%), dan terendah di Banten (1,6\%), sedangkan prevalensi ketulian tertinggi ditemukan di Maluku $(0,45 \%)$, Sulawesi Utara $(0,12 \%)$, dan terendah di Kalimantan Timur (0,03\%). ${ }^{3}$

Data Indonesia berdasarkan Survei kesehatan Indra Penglihatan dan Pendengaran tahun 1994-1996 juga menunjukkan morbiditas yang tinggi; penyakit telinga 18,5\%, prevalensi gangguan pendengaran $16,8 \%$ sedangkan ketulian didapatkan pada $0,4 \%$ populasi dan paling tinggi pada kelompok usia sekolah (7-18 tahun). Angka gangguan pendengaran dan ketulian di Indonesia masih tinggi dan telah menjadi masalah sosial yang perlu ditanggulangi secara terkoordinasi dengan melibatkan berbagai sektor terkait. Survei yang dilaksanakan di tujuh provinsi di Indonesia menunjukkan penyakit telinga luar (6,8\%), penyakit telinga tengah $(3,9 \%)$, dan presbikusis (2,6\%). Penyebab terbanyak dari morbiditas telinga ialah serumen prob (3,6\%) dan penyebab terbanyak morbiditas telinga tengah ialah otitis media supuratif kronik (OMSK) tipe jinak (3,0\%). ${ }^{4,5}$

Survei yang juga dilakukan oleh FKUI prevalensi serumen prob pada anak-anak usia sekolah cukup tinggi. Sumbatan serumen ini dapat mengakibatkan gangguan pendengaran. Gangguan pendengaran pada seorang anak akan menunjukkan 3 hal penting, yaitu kelainan perkembangan, menurunnya hasil belajar, dan kesulitan dalam penyesuaian dalam pergaulan. ${ }^{6}$

Penelitian ini bertujuan untuk mendapatkan tingkat kesehatan telinga pada siswa di SMA Negeri 9 Manado.

\section{METODE PENELITIAN}

Penelitian ini menggunakan metode deskriptif observasional, dengan pendekatan potong lintang. Penelitian ini dilakukan di SMA Negeri 9 Manado. Populasi penelitian ialah siswa-siswi SMA Negeri 9 Manado. Sampel penelitian ini ialah siswa-siswi SMA Negeri 9 Manado yang bersedia melakukan pemeriksaan THT-KL. Variabel penelitian ialah jenis kelamin dan gangguan/kelainan telinga.

\section{HASIL PENELITIAN}

\section{Karakteristik subjek}

Penelitian ini dilaksanakan pada bulan November 2015 di SMA Negeri 9 Manado kecamatan Sario Kota Manado. Tempat pemeriksaan subjek penelitian di dalam kelas X MIA 4. Sampel penelitian berjumlah 35 siswa yang berumur 13-16 tahun, terdiri dari 23 perempuan $(65,7 \%)$ 12 laki-laki (34,3\%) 
Tabel 1. Distribusi sampel berdasarkan jenis kelamin

\begin{tabular}{lcc}
\hline Jenis kelamin & $(\mathrm{n})$ & $\%$ \\
\hline Perempuan & 23 & 65,7 \\
Laki-laki & 12 & 34,3 \\
Total & 35 & 100 \\
\hline
\end{tabular}

\section{Hasil pemeriksaan \\ Daun telinga}

Pada pemeriksaan daun telinga pada siswa-siswi SMA Negeri 9 Manado didapatkan normal dan tidak didapatkan hasil yang abnormal.

Tabel 2. Distribusi sampel berdasarkan keadaan daun telinga

\begin{tabular}{ccccc}
\hline Keadaan & \multicolumn{2}{c}{$(\mathrm{n})$} & \multicolumn{2}{c}{$(\%)$} \\
daun telinga & Kanan & Kiri & Kanan & Kiri \\
\hline Normal & 35 & 35 & 100 & 100 \\
Abnormal & 0 & 0 & 0 & 0 \\
Total & 35 & 35 & 100 & 100 \\
\hline
\end{tabular}

\section{Liang telinga}

Pada pemeriksaan linag telinga siswa siswi SMA Negeri 9 Manado didapatkan hasil serumen pada siswa sebanyak 10 orang (28\%) di telinga kanan dan kiri, juga didapatkan 1 siswa (3\%) serumen hanya pada telinga kiri. Didapatkan pula oedem telinga kanan dan kiri pada 1 siswa (3\%).

Tabel 3. Distribusi sampel berdasarkan keadaan liang telinga

\begin{tabular}{ccccc}
\hline Keadaan & \multicolumn{2}{c}{$(\mathrm{n})$} & \multicolumn{2}{c}{$(\%)$} \\
\cline { 2 - 5 } liang & & & & \\
telinga & Kanan & Kiri & Kanan & Kiri \\
\hline Normal & 24 & 23 & 69 & 66 \\
Serumen & 10 & 11 & 28 & 31 \\
Edem & 1 & 1 & 3 & 3 \\
Total & 35 & 35 & 100 & 100 \\
\hline
\end{tabular}

\section{Membran timpani}

Pada pemeriksaan membran timpani siswa siswi SMA Negeri 9 Manado didapatkan hasil normal telinga kanan dan kiri sebanyak 32 orang (91\%), terdapat perforasi, retraksi, dan bombans 1 orang
(3\%) telinga kanan dan kiri, dan membran timpani sulit dievaluasi sebanyak 2 orang (6\%).

Tabel 4. Distribusi sampel berdasarkan keadaan membran timpani

\begin{tabular}{lcccc}
\hline Keadaan Membran & \multicolumn{2}{c}{ (n) } & \multicolumn{2}{c}{ (\%) } \\
\cline { 2 - 5 } timpani & Kanan & Kiri & Kanan & Kiri \\
\hline $\begin{array}{l}\text { Normal } \\
\begin{array}{l}\text { Perforasi, Retraksi, } \\
\text { dan bombans }\end{array}\end{array}$ & 32 & 32 & 91 & 91 \\
$\begin{array}{l}\text { Tidak } \\
\text { dievaluasi dapat }\end{array}$ & 1 & 1 & 3 & 3 \\
\begin{tabular}{l} 
Total \\
\hline
\end{tabular} & 2 & 2 & 6 & 6 \\
\hline
\end{tabular}

\section{BAHASAN}

Pada penelitian ini sampel yang bersedia mengikuti penelitian sebanyak 35 orang. Berdasarkan karakteristik jenis kelamin sampel penelitian terdiri atas 23 orang perempuan $(65,7 \%)$ dan 12 orang laki-laki (34,3\%).

Berdasarkan pada hasil pemeriksaan daun telinga siswa-siswi SMA negeri 9 manado didapatkan semua normal dan tidak ada kelainan telinga kanan maupun telinga kiri. Kemudian pada pemeriksaan liang telinga, didapatkan hasil serumen pada siswa sebanyak 10 orang (28\%) di telinga kanan dan kiri, juga didapatkan 1 siswa (3\%) serumen hanya pada telinga kiri. Serumen secara normal memang dapat ditemukan pada telinga, serumen memiliki fungsi proteksi. Serumen dapat mengumpul dan dapat membentuk massa serumen obsturan yang dapat menyumbat liang telinga. Berbagai faktor berkaitan dalam pembentukan serumen yaitu faktor internal seperti kelainan anatomis liang telinga, sekret serumen berlebihan, kelainan sistemik, aktifitas bakteri dan jamur dalam telinga berperan sebagai pembentuk serumen obsturan. Sedangkan faktor eksternal seperti cara membersihkan liang telinga, kelembapan udara yang tinggi, serta lingkungan yang berdebu juga berperan dalam pembentukan serumen obsturan. ${ }^{7,8}$ Pada pemeriksaan liang juga didapatkan oedem pada 1 orang (3\%). 
Untuk pemeriksaan mebran timpani siswa-siswi SMA Negeri 9 manado didapatkan hasil normal telinga kanan dan kiri sebanyak 32 orang (91\%), terdapat perforasi, retraksi, dan bombans 1 orang (3\%) telinga kanan dan kiri. Perforasi dapat disebabkan oleh karena infeksi seperti otitis media supuratif baik akut maupun kronik, kolesteatoma, barotrauma dan adanya trauma. $^{7,8}$ Dari pemeriksaan ini juga terdapat 2 (6\%) orang dengan membran tidak dapat di evaluasi. Membran timpani yang tidak dapat dievaluasi kemungkinan karena adanya cerumen probe, liang telinga yang sempit dan sikap yang tidak kooperatif dari sampel atau responden penelitian.

Dari keseluruhan pemeriksaan siswasiswi SMA Negeri 9 manado menunjukkan serumen pada telinga siswa masih cukup tinggi, disertai penemuan lain seperti edem dan perforasi pada membran timpani. Hal ini mungkin dipengaruhi oleh beberapa faktor seperti tingkat pengetahuan dan perilaku dalam hidup bersih, pencegahan dan penanganan dini dari penyakit. Adapun penemuan-penemuan lain pemeriksaan fisik seperti edem dan perforasi diperlukan edukasi pada orang tua untuk pemeriksaan serta penanganan yang lebih lanjut difasilitas kesehatan yang lebih lengkap.

Hasil penelitian ini masih memiliki banyak keterbatasan dan kekurangan, serta belum dapat dijadikan tolak ukur dalam penilaian status kesehatan telinga secara umum sehingga perlu di lakukan penelitan lanjutan dengan populasi yang lebih besar.

\section{SIMPULAN}

Dari hasil penelitian survei kesehatan telinga pada 35 siswa-siswi SMA Negeri 9 Manado dapat disimpulkan bahwa sebagian besar siswa SMA Negeri 9 Manado memiliki hasil normal. Meskipun demikian penemuan serumen pada telinga masih cukup banyak, disertai penemuan lain seperti sekret pada liang telinga dan adanya perforasi pada membran timpani.

\section{SARAN}

Disarankan adanya peran serta orang tua dan lingkungan sekitar dalam pemberian motivasi dan pengetahuan perilaku hidup bersih mengenai kesehatan telinga dan pendengaran. Selain itu, promosi dan penyuluhan kesehatan telinga dan pendengaran pada anak dan masyarakat perlu ditingkatkan

\section{DAFTAR PUSTAKA}

1. Djaafar ZA, Helmi, Restuti RD. Kelainan telinga tengah. In: Soepardi EA, Iskandar $\mathrm{N}$, Bashiruddin J, Restuti RD, editors. Buku Ajar Ilmu Penyakit THT (6th ed). Jakarta: Balai Penerbit FKUI, 2007; p. 6477.

2. Hafil AF, Sosialisman, Helmi. Kelainan telinga luar. In: Soepardi EA, Iskandar N, Bashinuddin J, Restuti RD, editors. Buku Ajar Ilmu Penyakit Ilmu THT (6th ed). Jakarta: Balai penerbit FKUI, 2007; p. 5763.

3. Trihono. Riset Kesehatan Dasar tahun 2013. Jakarta: Badan Penelitian dan Pengembangan Republik Indonesia, 2013.

4. Kementrian Kesehatan Republik Indonesia. Telinga Sehat Pendengaran Baik. C2014. Available from: http://depkes.go.id/index.php/berita/PressRelease/840-Telinga -Sehatpendengaranbaik.html

5. Keputusan Menteri Kesehatan Republik Indonesia No. 879/Menkes/SK/XI/2006 Tentang Rencana Strategi Nasional Penanggulangan Gangguan Pendengaran dan Ketulian untuk mencapai sound hearing 2030

6. Soetirto I, Hendarmin $H$, Bashiruddin $J$. Gangguan Pendengaran. In: Soepardi EA, Iskandar N, Bashiruddin J, Restuti RD, editors. Buku Ajar Ilmu Penyakit THT (6th ed). Jakarta: Balai penerbit FKUI, 2007; p. 10-16.

7. Petersen E, Hoskin M, Spahn I, et al. The Healthline Editorial Team. Anatomy of Ears. $2015 . \quad$ Available From:http:/www.healthline.com/humanbody-maps/ear

8. Soepardi EA. Pemeriksaan THT-KL. In: Soepardi EA, Iskandar N, Bashiruddin J, Restuti RD, editors. Buku Ajar Ilmu Penyakit THT (6th ed). Jakarta: Balai penerbit FKUI, 2007; p. 1-3. 